\title{
Et tilbakeblikk på selvmordsforebyggende arbeid
}

\author{
Nils Retterstøl intervjues av Elin Skogen
}

\begin{abstract}
- Valget mellom å leve og å dø er det grunnleggende, det helt sentrale anliggende i filosofien. Det er også det helt essensielle i psykiatrien, fastslår nestor i suicidologi Nils Retterstøl. - Selvmord er den mest ytterliggående handling et menneske kan foreta. Noe som aldri kan gjøres om. Ikke sjelden et uttrykk for det ytterste tilfellet av håpløshet. Hvorfor vil vi leve? Hvorfor vil vi dø? Intet tenkende menneske kommer utenom disse spørsmålene.
\end{abstract}

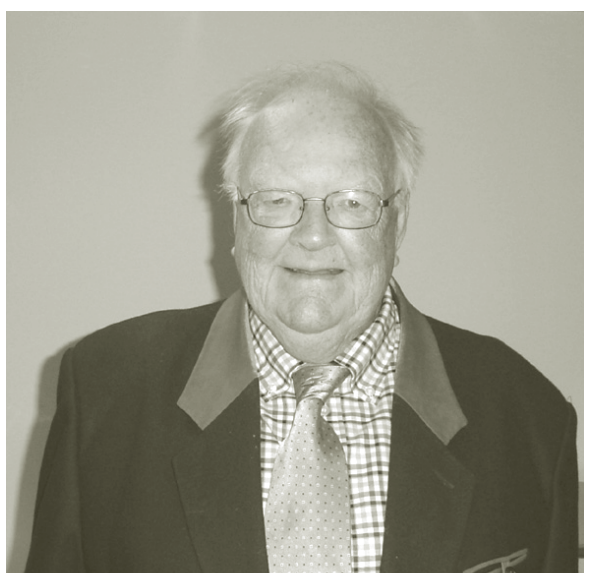

- Jeg var ferdig utdannet lege i 1950. Den gang var undervisningen lite fokusert på selvmordsproblematikk. Da jeg på slutten av 50-tallet begynte på Ullevål sykehus som psykiatrisk konsulent på Medisinsk avdeling, ble jeg stilt overfor store utfordringer i mitt møte med pasienter som hadde fors $\varnothing \mathrm{kt}$ å ta sitt eget liv og etterlatte etter selvmord, minnes professor i psykiatri Nils Retterst $\varnothing 1$.

- Jeg var fattig på kunnskap om dette emnet, og mitt møte med disse menneskene var sterkt. Jeg m $\varnothing$ tte mennesker preget av følelse av meningsløshet og mangel på håp. De etterlatte etter selvmord var ofte preget av bitterhet, skyldfølelse, skam og selvanklager. Selvmordsproblematikk var et "ikke-tema". Taushet var gull, og oppfølgingen nærmest lik null. På den tiden var forekomsten av selvmord i Norge 7-8 personer per 100000 innbyggere per år.

- I min periode på Ullevål sykehus ervervet jeg meg en god del erfaring, fortsetter Retterst $\varnothing$ l. - En ting var sikkert, vi psykiatere kunne ikke sitte med hendene $\mathrm{i}$ fanget og late som om problemet ikke eksisterte. Noe måtte gjøres, fastslår han.

\section{Forskningens spede begynnelse}

- Jeg begynte for alvor å interessere meg for dette tabubelagte emnet, og tok fatt på vitenskapelige unders $\varnothing$ kelser ved siden av pasientbehandling. Jeg gjorde en kartlegging av bruk og misbruk av barbiturater, sovemidlene som den gang var vanlig å bruke, og forgiftninger. Sammenhengen mellom overdose av disse pillene og selvmord syntes klar. Flere av arbeidene, i samarbeid med andre forskere, kom i både norske og internasjonale fagtidsskrifter.

- Fra 1958 til 1968 arbeidet jeg på Universitetets psykiatriske klinikk på Vinderen. Her begynte jeg med en etterunders $\varnothing$ kelse hvor jeg så på hvordan det hadde gått med personer 10-15 år etter at de hadde fors $\varnothing \mathrm{kt}$ å ta sitt eget liv.

For dette arbeidet (Long-Term Prognosis after Attempted Suicide) fikk Retterst $\varnothing 1$ H.M. Kongens gullmedalje i 1969.

- På en internasjonal selvmordskongress i 1969 var jeg så heldig å komme i kontakt med en av verdens ledende på dette området, professor Erwin Stengel ved Universitetet i Sheffield. Det var starten på et produktivt samarbeid som skulle få store ringvirkninger. Jeg inviterte professor Stengel som foreleser ved Universitetet i Bergen og til å undervise ved Neevengården sykehus hvor jeg fra 1969 til 1973 var ansatt som overlege og direkt $\varnothing$ r.

\section{Internasjonalt samarbeid}

- Økningen i selvmordshyppigheten etter 1970 viste klart at arbeidet måtte intensiveres. Fra 1970 til 1989 skjedde det en fordobling i antallet selvmord, som var på sitt høyeste i 1988 med 708 registrerte selvmord, altså nesten 17 selvmord per 100000 innbyggere per år. Nå gjaldt det å få politikerne på banen.

- I 1973 satte vi i gang et eget norsk kurs i selvmordslære i regi av Lægeforeningens etterutdanningsenhet. Det ble etter hvert en tverrfaglig virksomhet hvor leger, sykepleiere, psykologer og lærere var med. - Samtidig begynte det å skje ting i Norden. I 1977 etablerte de nordiske regjeringer Nordisk planleggingsgruppe for selvmordsforskning og -forebygging, og nedsatte en gruppe hvor representanter fra de nordiske landene m $\varnothing$ ttes med jevne mellomrom. I tre år var jeg leder i denne gruppen som satt sammen i seks år.

Retterst $\varnothing 1$ var også tidlig med i den internasjonale organisasjonen for selvmordsforebygging (IASP). I egenskap av organisasjonens president (1989-1991) ble han en av lederne da Verdens helseorganisasjon arrangerte et stort europeisk seminar i Szeged i Ungarn i 1989. Hvert land rapporterte om sitt arbeid på det selvmordsforebyggende feltet. I de fleste land var forebyggingen kommet svært kort. Finland pekte seg ut som et foregangsland. Der hadde man allerede etablert et nasjonalt program for forebygging av selvmord.

\section{Fra forsømmelse til resultat}

- Straks jeg kom hjem fra seminaret, satte jeg meg ned og skrev til Helsedirektoratet om hvor dårlig det var fatt med selvmordsforebyggende tiltak i Norge. Dette til tross for at selvmordshyppigheten hadde hatt en uhyggelig $\varnothing \mathrm{kning}$ de siste 20 årene. Brevet førte til at jeg ble innkalt til et møte i departementet, og det ble nedsatt et utvalg for å få utarbeidet et selvmordsforebyggende program på nasjonal basis. Jeg var leder for referansegruppen som var i virksomhet fra 1990 til 1993.

- Parallelt med dette ble det holdt en rekke tverrfaglige kurs i selvmordsforebygging i regi av fylkeslegene rundt om i landet. Ca. 10000 fagfolk gjennomgikk disse kursene $f \varnothing r$ handlingsplanen kom i gang, minnes Retterst $\varnothing$ l.

- Det var professor Øivind Ekeberg, som med grundig kjennskap til selvmordsproblematikk, selvmordsfors $\varnothing \mathrm{k}$ og forgiftninger sto for hovedarbeidet med å utarbeide et forslag til nasjonalt program for selvmordsforebygging, fortsetter han. 
- Neste skritt var at det i 1994 ble lagt frem en handlingsplan mot selvmord. Endelig tok Norge, som ellers går for å være fremskrittsvennlig og humant, landets regjering og styringsverk, selvmordsproblemene på alvor.

- I 1996 ble dette selvmordsforebyggende arbeidet fulgt opp ved etableringen av Seksjon for selvmordsforskning og forebygging (ved Universitetet i Oslo, Det medisinske fakultet). Seksjonen holder til på Gaustad sykehus. Lars Mehlum har vært leder av seksjonen siden 1996, og han fikk landets forste professorat i suicidologi i 1999. I dag ligger Norge langt fremme når det gjelder selvmordsforskning og forebyggende arbeid. Nå er det også etablert regionale sentra i Bergen, Trondheim og Troms $\varnothing$. Så vi har gått veien fra fors $\varnothing$ mmelse til resultater i løpet av ganske få år, konstaterer han forn $\varnothing y d$.

- Etter at det selvmordsforebyggende program kom i gang, har selvmordshyppigheten gått betydelig ned her i landet. At stadig færre d $\varnothing \mathrm{r}$ av overdoser, har nok sammenheng med at nye, og i denne sammenheng mer ufarlige, antidepressive midler har erstattet de gamle "selvmordspreparatene", som var svært giftige. Vi kan ikke si sikkert hvor mye Handlingsplan mot selvmord har betydd for det klare fallet i antall selvmord i Norge siden 1989, men siste tilgjengelige dødsårsaksstatistikk (2003) fra Statistisk sentralbyrå viser at selvmordshyppigheten nå er nede i 11 pr. 100000 per år. En svært klar og svært gledelig nedgang.

\section{Før og nå}

- De medisinske avdelingene på 50-tallet gjorde jobben med å behandle forgiftningen. Av de som kom levende inn i sykehus, kom nesten alle levende fra selvmordsfors $\varnothing$ ket. De overlevde, men fikk bortimot ingen oppfølging. Fremdeles behandles forgiftningene på våre medisinske avdelinger med svært gode resultater, men til forskjell fra på 50-tallet får de fleste pasientene i dag nødvendig oppfølging. Foreligger det en psykisk sykdom, blir innleggelse i psykiatrisk avdeling aktuelt.
- På 50-tallet var bruken av tvang mye mer vanlig. Når vi nå konstaterer at det har vært en $\varnothing$ kning $\mathrm{i}$ antall selvmord $\mathrm{i}$ psykiatriske avdelinger frem til i dag, vil jeg tro at dette nok skyldes større åpenhet og frihet i våre psykiatriske institusjoner. Mens bruken av tvang lå litt mer i kortene før i tiden, er vi i dag mye mer tilbakeholdne.

- Vi må stadig arbeide for bedre og mer tilgjengelig behandling. Institusjonene kan også gå sine rutiner nærmere i sømmene. Og ikke minst er det viktig å etablere et godt organisert ettervern. Det er også svært viktig at etterlatte etter selvmord blir fulgt opp. I fremtiden vil samarbeidet med denne gruppen forhåpentligvis bli mer sentralt. Flere kommuner tilbyr sorggrupper, og LEVE, Landsforeningen for etterlatte ved selvmord spiller en uvurderlig rolle i dette arbeidet.

\section{Forebyggende arbeid}

- Når det gjelder de unge, har ikke selvmordstallet gått særlig ned fra 1988 til i dag. Det er tungt å konstatere for en som har viet så mye av sin tid til selvmordsbekjempelse, sier Retterst $\varnothing$ l.

- Mange unge har det tungt i dag. Til tross for at det materielt sett har vært en eksplosiv bedring i etterkrigstidens Norge, har ikke de unge flest fått det lettere, fortsetter han ettertenksomt. - Verdiene er i endring. Storfamilien er nærmest blitt borte i det moderne Norge. Tryggheten som lå i daglig kontakt mellom flere generasjoner, er nesten umulig å erstatte. Allerede fra barnsben av går mange glipp av en trygghet som tidligere betydde så mye. Færre henter styrke i et kristent livssyn. Mange føler seg som verdil $\varnothing$ se tapere i et samfunn der tilpasningsevne og vellykkethet står i fokus. Misbruk av alkohol og narkotika er et $\varnothing$ kende problem. For rotløse mennesker, mennesker uten forankring, kan tilværelsen virke ganske meningsløs. Og for den som eksisterer i et verdimessig og åndelig vakuum, kan tanken bli påtrengende:

Tenk å få slippe. Hvorfor ikke gjøre slutt på det hele? Det blir en ond sirkel enkelte ikke ser noen mulighet til å bryte. Ingen annen enn det uavvendelige, den ultimate handling: $\AA$ ta sitt eget liv.
- Vurdering av selvmordsfare er en av de vanskeligste oppgaver innen medisin og psykiatri. Selv erfarne fagfolk kan oppleve at en pasient tar sitt eget liv i tilfeller hvor man har vurdert selvmordsfaren som liten. Det første vi må være klar over, er at alle som forteller om selvmordstanker eller truer med å ta livet sitt, må tas på alvor, understreker han bestemt.

- Det er gjort konkrete forebyggende tiltak de senere årene. De tricykliske antidepressive medikamentene, som tidligere ble mest anvendt ved depresjon, og som var mer "selvmordsfarlige" er, som tidligere nevnt, byttet ut med nyere og mindre giftige preparater, informerer han videre.

- Andre eksempler på forebyggende tiltak som kan gjøres, er å redusere tilgang på våpen og å sikre broer med tanke på å redusere faren for selvmord. I tillegg har Seksjon for selvmordsforskning og -forebygging satt i gang videreutdanning i selvmordsforebyggende arbeid. Et deltidstudium som går over to år med avsluttende eksamen. Utdanningen er tverrfaglig og beregnes på leger, psykologer, sykepleiere, kliniske sosionomer og andre som i sitt daglige arbeid har, eller vil møte mennesker som har fors $\varnothing$ kt å ta sitt eget liv og etterlatte ved selvmord. Dette vil gi ringvirkninger over hele landet, fastslår han forn $\varnothing y d$.

- Selvmord og selvmordsproblematikk er noe av det vanskeligste innen medisin og psykiatri. Ikke sjelden et uttrykk for det ytterste tilfellet av håpløshet. Da gjelder det å gripe håpet, tenne den gnisten som gjør at livet tross alt er verdt å leve. Det gjelder også dem som ennå ikke har fors $\varnothing \mathrm{kt}$, men som til stadighet sysler med muligheten for selv å sette det endelige punktum for sin jordiske tilværelse. Dette arbeidet nytter! Av dem som legges inn i psykiatriske institusjoner etter et fors $\varnothing \mathrm{k}$ vil ca 10 prosent $\mathrm{d} \varnothing$ for egen hånd, men 90 prosent gjør det ikke.

- $\AA$ bli hørt er viktig. Her syndes det mye, tror jeg, også i dagens psykiatri. En av legenes og psykiaternes fremste oppgave er å redde liv, og gjøre livet mest mulig leveverdig. Her b $\varnothing$ r intet være upr $\varnothing v d$, avslutter Nils Retterst $\varnothing$ l. 